\title{
NILAI-NILAI MORAL NOVEL PETER KARYA RISA SARASWATI DAN RELEVANSINYA DENGAN PEMBELAJARAN BAHASA INDONESIA
}

\author{
Endang Rahmawati dan Ferdian Achsani \\ Institut Agama Islam Negeri Surakarta \\ erharahmawati@gmail.com
}

\section{ABSTRAK}

\section{ABSTRACT}

Nilai moral merupakan nilai yang berkaitan dengan baik buruk tingkah laku manusia dalam kehidupan. Berkaitan dengan moral, karya sastra khususnya novel dan kehidupan masyarakat merupakan dua hal yang tidak dapat dipisahkan. Novel merupakan gambaran realitas kehidupan yang digambarkan oleh pengarang berdasarkan pengalaman dan ungkapan perasaan pribadi. Senda dengan hal tersebut, pembelajaran bahasa Indonesia dapat dilakukan melalui kegiatan apresiasi. Apresiasi meruapakan suatu kegiatan menilai, memahami dan menghayati sebuah karya sastra. Pengajaran sastra dapat dilakukan dengan memperkenalkan sastra pada peserta didik agar dapat memahami, merasakan dan memetik nilai-nilai dalam sebuah karya sastra. Metode yang digunakan dalam penelitian ini adalah metode deskriptif kualitatif. Diskriptif kualitatif dengan teknik analisis isi ini menguraikan setiap kutipan dalam novel yang mencerminkan perilaku moral sebagai sumber data. Teknik pengumpulan data dalam penelitian ini yaitu teknik catat. Peneliti membaca novel Peter karya Risa Saraswati secara berulang demi mengetahui makna cerita dalam novel tersebut. setelah mengetahui makna dalam cerita, peneliti menandai setiap kutipan yang mencerminkan pesan moral, kemudian mencatatnya dalam lembar yang sudah di sediakan. Hasil penelitian menunjukkan bahwa pesan moral yang terdapat dalam novel tersebut seperti: kasih sayang orang tua, nasionalisme, percaya diri, bersahabat, menghargai orang lain, sopan santun, peduli lingkungan, peduli sesama, religius, menghargai tamu. Melalui pesan moral tersebut, menjadikan novel ini relevan sebagai bahan pembelajaran bahasa Indonesia. Hal ini dikarenakan bahwa pendidikan tidak hanya sebagai transfer ilmu pengetahun namun juga pembentukan moral spiritual, sehingga melalui beberapa pesan moral yang terdapat dalam novel tersebut diharapkan dapat diteladani oleh pembaca terutama peserta didik.

Kata Kunci: nilai moral, novel Peter karya Risa Saraswati, relevansi pembelajaran bahasa Indonesia

Moral values are values that are related to both bad human behavior in life. With regard to morals, literature, especially novels and people's lives are two things that cannot be separated. The novel is a description of the reality of life described by the author based on experience and expression of personal feelings. With that, Indonesian language learning can be done through appreciation 
activities. Appreciation is an activity of assessing, understanding and living a literary work. Teaching literature can be done by introducing literature to students in order to understand, feel and reap the values in a literary work. The method used in this study is a qualitative descriptive method. Qualitative descriptive with content analysis techniques describes each quote in a novel that reflects moral behavior as a source of data. The data collection technique in this study is the note-taking technique. The researcher reads Risa Saraswati's Peter novel repeatedly to find out the meaning of the story in the novel. after knowing the meaning in the story, the researcher marks each quote that reflects the moral message, then records it in the sheet provided. The results showed that the moral messages contained in the novel were: parental affection, nationalism, self-confidence, friendliness, respect for others, courtesy, caring for the environment, caring for others, religious, respecting guests. Through this moral message, making this novel relevant as an Indonesian learning material. This is because education is not only a transfer of knowledge but also the formation of spiritual morality, so that through some moral messages contained in the nvoel, it is expected to be emulated by readers, especially students.

Keywords: moral value, Peter novel by Risa Saraswati, relevance of Indonesian language learning

Moral merupakan suatu hal yang selalu menjadi bahan hangat pembicaraan. Moral berkaitan dengan tabiat, perilaku dalam menjalani kehidupan sehari-hari. Nilai moral merupakan nilai yang berkaitan dengan baik buruk tingkah laku manusia dalam kehidupan. Seseorang dikatakan bermoral apabila memiliki kepribadian baik dan dapat diterima oleh masyarkat. Sebaliknya orang yang dikatakan tidak bermoral adalah yang tidak mematuhi tingkah laku yang sudah membudidaya dalam kehidupan masyarakat. Yusuf (2004) mengatakan bahwa nilai-nilai moral tersebut seperti: seruan untuk berbuat baik kepada orang lain, memelihara kebersihan dan hak orang lain, larangan mencuri, berzina, membunuh, meminum-minuman keras dan berjudi. Lain halnya dengan Yusuf, Hidayat (2014) mengatakan bahwa moral muncul dalam bentuk kesesuaian dan keharmonian seseorang dalam beraktivitas dengan norma-norma yang meliputi norma kesopanan, norma adat, norma tradisi, dan norma sosial.

Belakangan ini masyarakat Indonesia sedang mengalami degradasi moral, terutama di kalangan remaja. Ningrum (2015) menyatakan beberapa perilaku penyimpangan moral remaja seperti pergaulan bebas dan seks bebas hingga menyebabkan hamil di luar nikah. Selain itu juga ditandai dengan beberapa fenomena seperti lunturnya sikap saling menghormati, menghargai, dan toleransi. Manusia menjadi sosok individualis dan acuh pada kehidupan sosial. Harta dan tahta semakin diperebutkan melalui berbagai cara, hingga membuat manusia belomba-lomba untuk saling disanjung tanpa memiliki rasa rendah hati. Arus globalisasi yang semakin 
pesat tidak digunakan dengan bijak oleh para penggunanya, malah digunakan dengan menyebar berita hoax yang mudah memprofokasi dan dijadikan untuk saling menghujat dan menebar kebencian.

Baik buruk kualitas suatu bangsa dilihat dari perilaku moral penduduknya. Apabila penduduknya baik, maka negara tersebut dapat dikatakan baik, sebaliknya apabila moral masyarakat buruk, maka buruk pula bangsa tersebut. Untuk itu perlunya pengajaran moral sejak dini agar masyarakat dapat memahami antara hal yang baik dan yang buruk. Pendidikan merupakan salah satu sarana sebagai wadah untuk membentuk moral anak. Pembentukan moral anak sejak dini diharapkan dapat menjadikan pribadi yang bermoral di kemudian hari.

Senada dengan hal tersebut, pembelajaran moral di sekolah dapat diintegrasikan dalam setiap materi pembelajaran yang disampaikan oleh guru. Dengan model pembelajaran yang terintegrasi moral, maka semua guru dapat dikatakan sebagai pengajar moral (Budiningsih, 2008). Bukan hanya guru maja pelajaran Pendidikan Kewarganegaraan atau Pendidikan Agama yang berperan dalam pembentukan moral anak, akan tetapi semua guru mata pelajaran memiliki peran dalam membentuk moral anak.Pembentukkan moral siswa tidak luput dari media yang digunakan untuk mempermudah proses pembelajaran (Riyanti \& Inung, 2017). Dengan adanya media yang digunakan dalam pembelajaran, maka pesan yang ingin disampaikan akan lebih terarah dan mudah untuk dipahami bagi peserta didik.

Salah satu media yang dapat digunakan untuk mengajarkan moral adalah buku. Muhtadi (2016) menyatakan bahwa buku menjadi media informasi yang sangat penting karena didalamnya terdapat ilmu pengetahuan, hiburan, dan dapat menjadi teman dekat bagi pembaca. Melalui membaca sebuah buku seseorang akan memperoleh banyak informasi dan pengetahuan baru. Misalnya guru bahasa Indonesia dapat menggunakan novel sebagai bahan media pembelajaran sekaligus pembentuk moral siswa.

Karya Sastra khususnya novel dan kehidupan masyarakat merupakan dua hal yang tidak dapat dipisahkan. Novel merupakan gambaran realitas kehidupan yang digambarkan oleh pengarang berdasarkan pengalaman dan ungkapan perasaan pribadi yang dibentuk berdasarkan unsur-unsur seperti tema, tokoh, latar, sudut pandang, alur, gaya bahasa dan amanat. Pengalaman tersebut digambarkan dalam bentuk tulisan yang mampu memengaruhi kehidupan pembaca. Novel selalu menampilkan dunia yang aneh dan penuh dengan sensasi sebagai pengalaman hidup yang nyata (Endawarsana, 2013). Gambaran realitas kehidupan yang digambarkan melalui perilaku para tokoh dalam berinteraksi dengan tokoh lain (manusia), tuhan dan lingkungan tersebut memiliki tujuan, yaitu memberikan nilai didik bagi pembaca. Suatu karya sastra (novel) dapat dikatakan baik dan bermutu apabila ia memiliki nilai didik yang dapat diajdikan teladan bagi pembaca. 
Hal tersebutlah yang melatarbelakangi penggunaan novel sebagai media pembelajaran dan pembentukan moral anak.

Irma (2018) menyatakan bahwa Novel tidak hanya sebagai alat hiburan, tetapi juga sebagai bentuk karya seni yang menampilkan nilai-nilai baik buruk atau moral dalam kehidupan dan mengarahkan pada pembaca tentang budi pekerti yang luhur. Nilainilai yang terdapat dalam sebuah novel merupakan hal yang paling utama diciptakannya suatu novel. Hal ini bertujuan agar melalui nilai-nilai tersebut, pembaca dapat mengambil pelajaran dan dapat digunakan sebagai cerminan dalam kehidupan sehari-hari. Nilainilai yang terkandung dalam sebuah novel merupakan nilai-nilai yang sudah membudidaya atau niali yang sudah menjadi tradisi yang telah dianggap baik di lingkungan masyarakat. Nilai-nilai tersebutlah yang menjadi tujuan utama pengajaran sastra. Nilai-nilai moral tersebut, mengajak pembaca atau penikmat untuk menegakkannya dalam kehidupan sehari-hari (Suhardi, 2018).

Nilai moral merupakan salah satu nilai yang terdapat dalam sebuah novel. Hasil ini terkandung dalam fungsi moralitas sastra, yaitu sastra selalu memberikan pengetahuan moral yang baik dan buruk karena setiap karya sastra selalu memberikan pelajaran moral yang tinggi (Rokhmansyah, 2014). Untuk itulah Pengarang novel atau sastrawan selalu menampilkan pesan moral kepada pembaca melalui gambaran perilaku atau problematika yang dialami oleh para tokoh. Nilai moral dalam sebuah karya sastra ataupun novel tidak selalu ditampilkan melalui interaksi para tokoh protagonis. Terkadang pesan moral dalam sebuah novel juga ditampilkan melalui interaksi para tokoh antagonis. Tujuannya agar pembaca dapat memahami bahwa perbuatan buruk merupakan perbuatan yang tercela, sehingga pembaca dapat mengambil hikmah darinya. Melalui sebauh novel pembelajaran moral dapat dilakukan dengan pendidikan langsung dan indentifikasi. Pendidikan moral secara langsung artinya menanamkan pengertian moral tentang benar dan salah, sedangkan pendidikan moral secara identifikasi artinya penanaman moral dengan cara meniru penampilan atau tingkah laku seseorang.

Pembelajaran bahasa Indonesia dapat dilakukan melalui kegiatan apresiasi. Apresiasi meruapakan suatu kegiatan menilai, memahami dan menghayati sebuah karya sastra. Pengajaran sastra dapat dilakukan dengan memperkenalkan sastra pada siswa-siswi, agar siswa dapat memahami, merasakan dan memetik nilai-nilai dalam sebuah karya sastra (Mujiyanto \& Fuady, 2014). Sehingga kegiatan apresiasi sastra dapat dimaknai sebagai suatu kegiatan yang bertujuan agar siswa mampu mengenali dan memetik nilainilai yang terkandung dalam sebuah karya sastra, kemudian dapat diimplementasikan dalam kehidupan sehari-hari.

Kegiatan apreasasi karya sastra merupakan kegiatan yang bertujuan untuk memberikan penilai terhadap hasil suatu karya sastra. Kegiatan tersebut dalam pembelajaran dapat dilakukan seperti menganalisis struktur karya sastra, membuat resensi atau sinopsis. Pembelajaran apresiasi novel hanya ada dalam jenjang 
sekolah SMA/SMK/MA, untuk itu kegiatan apresiasi novel tidak dapat dilakukan di jenjang SMP/MTs. Kegiatan apresiasi tidak hanya dilakukan pada materi kesusastraan novel atau prosa. Jadi pada jenjang SMP/MTs kegiatan apresiasi karya sastra dapat dilakukan melalui pembelajaran puisi atau cerpen.

Berdasarkan uruaian di atas maka dapat disimpulkan bahwa Penelitian ini bertujuan untuk mendeskripsikan nilai-nilai moral dalam karya sastra novel. novel yang dipilih dalam penelitian ini adalah novel berjudul Peter karya Risa Saraswati. Novel ini menceritakan mengenai sahabat Risa bernama Peter semasa hidup. Kisah pilu yang dialami oleh Peter dalam novel bergenre semi horor ini, dapat dijadikan sebagai bahan pembelajaran bagi siswasiswi sekolah karena di dalamnya terdapat pesan moral yang dapat diteladani bagi pembaca.

METODE

\section{PEMBAHASAN}

Penelitian ini termasuk dalam penelitian deskriptif kualitatif. Diskriptif kualitatif dengan teknik analisis isi ini menguraikan setiap kutipan dalam novel yang mencerminkan perilaku moral sebagai sumber data. Teknik pengumpulan data dalam penelitian ini yaitu teknik catat. Peneliti membaca novel Peter karya Risa Saraswati secara berulang demi mengetahui makna cerita dalam novel tersebut. setelah mengetahui makna dalam cerita, peneliti menandai setiap kutipan yang mencerminkan pesan moral, kemudian mencatatnya dalam lembar yang sudah di sediakan. Hasil uraian tersebut kemudian ditampilkan dalam bentuk laporan ini.

\section{Nilai Moral \\ Kasih sayang orang tua pada anak}

Beatrice merangkul anaknya dengan cepat. Peter ketakutan dan mulai menangis, balas memeluk ibunya yang begitu terenyuh melihat anak mungilnya ketakutan mendengar bentakan sang ayah (Saraswati, 2017).

Kutipan di atas mencerminkan kasih sayang seorang ibu kepada anaknya. Peter yang merupakan anak satu-satunya dalam keluarga Van Gils, merupakan anak yang manja, dan kerap dimarahi oleh ayahnya, Albert. Albert melakukan hal tersebut karena ingin mendidik agar Peter menjadi laki-laki yang tangguh. Dalam kutipan di atas menceritakan bagaimana bentuk perlakukan Beatrice yang begitu sayang kepada anaknya. Setiap kali Peter dibentak oleh Albert, ia selalu berlindung dipelukan ibunya. Nilai moral dalam kutipan tersebut adalah Perilaku seorang ibu selalu berusaha melindungi anaknya bagaimana pun caranya karena anak merupakan tempat curahan hati orang tua.

Sebelum Meninggalkan kelas, Beatrice menghampiri bengku tempat anaknya duduk, lantas mencondongkan wajahnya kea rah kening peter, berusaha untuk memberikan kecupan seperti yang biasa dia berikan pada anak kesayangannya (Saraswati, 2017). 
Rasa kasih sayang yang ditunjukkan oleh Beatrice tidak hanya ditujukan ketika ia selalu melindungi Peter. Dalam kutipan di atas, Beatrice memberikan kecupan di kening anaknya sebagai bentuk kasih sayang ibu kepada anaknya. Bentukan kecupan yang diberikan oleh Beatrice kepada Peter memiliki arti bahwa ia memberikan semangat kepada anak semata wayangnya agar berani menghadapi sekolah dan semanagt dalam mengemban ilmu. Sang ibu berharap agar Peter semangat dalam menuntut ilmu di hari pertamanya sekolah.

\section{Nasionalisme}

"Beatrice! Geef hem over nederlands leren! Bagaimanapun dia anak netherland, bukan inlader. Dia harus bisa bicara bahasa netherland!" (Saraswati, 2017).

Hidup dan lahir di tanah jajahan ternyata berpengaruh terhadap penggunaan bahasa Peter. Ia lebih dominan menguasai bahasa Indonesia daripada menguasai bahasa aslinya. Hal itu terlihat ketika Albert meminta Peter untuk berbicara menggunakan bahasa Netherland, namun ternyata Peter tidak mampu. Albert marah besar kepadanya. Karena bagaimana pun, bahasa Netherland adalah bahasa asli dari negaranya. Ia seharusnya mampu mnguasai bahasa Netherland bukan bahasa Indonesia. Wujud nasionalisme yang dilakukan oleh Albert tersebut terlihat ketika ia sangat menginginkan anaknya untuk bisa menggunakan bahasa asal mereka ketika berkomunikasi. Dengan menggunakan bahasa asal ketika berkomunikasi, maka sama halnya dengan menghargai asset negara. Sehingga hal tersebut merupakan nilai moral nasionalisme.

Fisik albert mungkin memang kuat, tapi secara mental seperti ada peran batin di dalam dirinya. Di satu sisi, dia ingin berjuang atas nama bangsa. Tapi, di sisi lain, dia juga harus melindungi keluarganya (Saraswati, 2017).

Selain menjunjung tinggi bahasa asal mereka, wujud cinta tanah air juga di gambarkan dalam kutipan di atas, dalam kutipan tersebut menjelaskan bahwa Albert datang ke Indonesia karena ingin berjuang atas nama bangsanya, Belanda. Hal lain tersebut diperkuat dalam cerita yang mengunjukkan bahwa Albert merupakan seorang komandan di daerah tempat tinggal Peter. Sebagai seorang tentara, sudah pasti ia mempertaruhkan hidupmatinya demi melindungi bangsa dan negaranya. Hal tersebut dapat dikatakan bahwa Albert memiliki jiwa nasionalisme yang tinggi, sehingga melalui kutipan tersebut pembaca dapat mengambil pembelajaran bahwa setiap orang, tidak hanya abdi negara, wajib menjunjung tinggi persatuan dan kesatuan bangsa serta wajib melindungi bangsa dan Negara.

\section{Percaya diri}

Tetapi kekhawatirannya dipatahkan oleh sikap sang anak. Berulang kali Peter meyakinkan ibunya bahwa dia sama sekali 
tidak takut menghadapi sekolah. "aku tidak takut inlader, mama. Tenang saja!” dia meyakinkan, sambil memamerkan otot lengannya yang kurus kering (Saraswati, 2017).

Sebelum Beatrice mengizinkan Peter untuk sekolah, ia selalu meyakinkan padanya apakah ia benar-benar ingin sekolah. Kekhawatiran Beatrice terjadi ketika beberapa temannya sempat bercerita bahwa ia lebih memilih menyekolahkan anaknya di rumah dari pada harus menyekolahkan anaknya di HIS. Namun sikap percaya diri, rasa takut dan semangat yang dimiliki oleh Peter untuk ingin sekolah di HIS berhasil mematahkan kekhawatiran Betarice. Peter sangat yakin bahwa ia akan mampu dan berani dalam menghadapi sekolah, meskipun pada akhirnya ia menangis karena dipermalukan oleh teman-teman sekelasnya. Sikap percaya diri inilah yang wajib ditiru dan dicontoh. Jika seseorang menanamkan sikap percaya diri pada diri masing-masing, maka akan sanggup mengalahkan segala rintangan yang menghadang.

\section{Bersahabat}

Beberapa mata menatap peter dengan angkuh, sisanya menunjukkan sikap tak peduli. Hanya ada lima anak keturunan nethherland di kelas itu, dan kelimanya seolah tak peduli pada anak baru berambut pirang yang akan menjadi teman sekelas mereka (Saraswati, 2017).

Kutipan di atas menceritakan bagaimana keadaan kelas di sekolah HIS, ketika pertama kali Peter masuk ke kelas. Dalam kutipan tersebut menceritakan bagaimana teman-teman sekelas tersebut tidak ada satu pun yang peduli dengan kehadiran Peter. Mereka seolah acuh dan tak peduli dengan kehadirannya. Nilai moral yang dapat diambil dari perilaku yang dituliskan dalam kutipan tersebut adalah bahwa sesama teman hendaknya saling memiliki rasa kebersamaan, sehingga terjalin bentuk kekeluargaan. Bukan malah sebaliknya, bersikap dingin dan individual tidak akan mampu membentuk rasa kebersamaan. Sehingga sesama teman hendaknya saling peduli dan perhatian agar terjalin ikatan tali silaturahmi.

\section{Menghargai orang lain}

"Hallo, siapa kamu?” dia bertanya sambil menatap peter.

"saya tidak tahu," jawab peter pelan. Jawaban sontak membuat tawa kembali pecah tak terbendung.

Salah seorang anak perempuan berambut pirang berdiri sambil meneriakinya, "bodoh! Anak ini bodoh! Hahaha!" (Saraswati, 2017).

Kutipan di atas menceritakan ketika seorang guru bertanya tentang identitas Peter, namun Peter tak bisa menjawab. Peter hanya menjawab bahwa ia tidak tahu. Jawaban yang dilontarkan oleh Peter tersebut sontak mengundang cemooh dari teman-teman 
sekelasnya. Salah satu seorang pun berdiri dan meneriaki bahwa Peter merupakan anak yang bodoh. Anak tersebut mengatakan hal tersebut lantaran Peter tidak bisa menjawab pertanyaan dari gurunya. perilaku yang dilakukan oleh anak tersebut sangat tidak sesuai dengan etika. Anak tersebut tidak memiliki etika untuk menghormati orang lain. Seburuk apapun orang lain, seharusnya tidak boleh mencemoohnya. Seharusnya mendekati orang tersebut, mengajaknya belajar atau memberi tahunya dengan lembut, bukan justru mencemooh.

Kontan saja, tawa corie meledak pecah. "hahahahahah! Sudah kuduga! Aku juga mengira seperti itu! Kau tahu? Umurnya sepuluh tahun! Ahahhaah!" corie terus tertawa

Harry tak tertawa, sebaliknya dia terlihat marah mendengar ledekan corie. "corie! Kau tidak boleh bersikap begitu! Kau tahu, aku juga dulu pendek dan kecil. Ini hanya soal waktu! Suatu saat tubuhnya akan tinggi dan besar sepertiku” (Saraswati, 2017).

Harry dan Corrie merupakan sepasang kekasih. Meskipun Corrie sudah berumur 17 tahun, namun sikapnya masih kekanankkanakan. Hal itu terlihat ketika ia sering menertawakan Peter yang umurnya masih 10 tahun namun belum menunjukkan perkembangan fisik yang matang. Berbeda dengan Corrie, Harry tampak menunjukkan sikap kedewasaannya. Hal itu terlihat ketika ia memilih diam, katimbang mengikuti Corrie yang menertawakan Peter. Bahkan Harry pun terlihat marah ketika Corrie menertawakan Peter. Dalam hal ini, Harry telah menunjukkan sikap menghargai orang lain. Sikap yang ditunjukkan oleh Harry trsebut patut dan layak untuk di contoh, karena tidak sepantasnya seseorang menertawakan kekurangan orang lain. Belum tentu seseorang tersebut lebih baik dari yang ditertawakan.

\section{Sopan santun}

Tiba-tiba, anak itu berdiri dan naik ke meja tempar lauren menyimpan buku-bukunya. Peter menginjak buku-buku itu dan berteriak (Saraswati, 2017).

Peter memang anak yang manja. Bahkan ketika Lauren, guru pribadi Peter mengajarnya, ia selalu menolaknya lantaran guru tersebut merupakan wanita yang galak. Untuk mengusir Lauren agar tidak lagi mengajarinya, ia pun melakukan aksi dengan bertindak tidak sopan. Peter naik ke atas meja dan menginjak-injak buku pelajarannya. Tak hanya itu saja, ia pun memaki-maki Lauren untuk pergi dan jangan pernah kembali kerumahnya lagi. Perbuatan yang dilakukan oleh Peter tersebut sangat tidak sesuai dengan etika sopan santun yang berlaku. Sebenci apapun seseorang tehadap orang lain tidak sepantasnya berbuat yang tidak sopan hingga melukai perasaan orang lain. 
"kau sudah besar sekali, sayang! Terakhir kali aku melihatmu, kau masih dalam gendongan Beatrice, sudah lama skali. Berapa umurmu sekarang?” Tanya Sophia

"sepuluh" jawab peter sambil terus menunduk. Terdengar tawa terkikik salah seorang gadis kecil itu mendengar Peter menjawab pertanyaan Sophia. Seketika Peter mendongak.

"wat? Sepuluh tahun? Kupikir umurmu sama dengan Renee, tujuh tahun. Hahaha!” berani-beraninya Corie mengejek, padahal di depan ibunya (Saraswati, 2017).

Meskipun umur Peter yang sudah menginjak 10 tahun, akan tetapi pertumbuhan fisik Peter belum terlihat begitu signifikan. Hal itu mengundang cemooh dari Corrie. Perbuatan yang dilakukan oleh Corrie tersebut tidak sepntasnya dilakukan. Seburuk apapun orang lain tidak sepanatsnya saling mengejek atau mencemoohnya. Perkataan yang dilontarkan oleh Corrie dalam kutipan termasuk dalam pelanggaran moral sopan santun, sehingga dapat diambil pembelajaran bahwa antarumat manusia ciptaan tuhan harus saling menghargai. Mencemooh orang lain sama halnya tidak menghargai ciptaan tuhan.

\section{Peduli lingkungan}

"Jangan pernah lakukan itu ok? Kalau kau menyakiti bunga dan segala tumbuhan, berarti kamu menyakiti mama. Mengerti?" Beatrice menatap anaknya (Saraswati, 2017).

Kutipan di atas terjadi ketika Beatrice mengajak Peter untuk belajar mengenal lingkungan. Peter kala itu ingin menyobek bunga kertas, namun seketika Beatrice langsung menghentikan ulahnya tersebut. Beatrice pun menunjukkan kepeduliannya kepada Peter bahwa setiap makhluk ciptaan Tuhan harus mencintai lingkungan. Betrice mnegibaratkan jika Peter menyakiti tumbuhan, maka sama halnya ia menyakiti ibunya.

\section{Peduli Sosial}

"Papa kami memang boros, sama seperti Corrie. Menurutku, kemewahan ini berlebihan, padahal orang-orang pribumi yang bekerja di rumah ini sangat miskin. Aku kasihan pada mereka." Suzana terus berjalan tak mengindahkan Peter yang ingin berhenti sejenak (Saraswati, 2017).

Kutipan tersebut menjelaskan kepedulian Suzana yang merasa kasihan melihat para pribumi yang miskin dan bekerja di rumahnya. Kepeduliannya tersebut timbul ketika ia merasakan hidup kemewahan dan melihat kehidupan pribumi yang miskin dan jauh dari kemewahan. Keluarga Albert merupakan keluarga yang kaya raya. Sehingga, Albert menjadi orang yang boros. Namun Albert tak sedikit pun melihat bahwa disekelilingnya banyak orang miskin, yang kehidupannya berbeda dari kehidupannya. Melalui kutipan tersebut dapat diambil pembelajaran bahwa sebahagianya hidup 
manusia, harus selalu ingat bahwa di bawahnya masih banyak orang-orang yang membutuhkan uluran tangan.

\section{Religious}

"lalu, apa benar orang yang sudah meninggal bisa tak pulang ke pangkuan tuhan?" dia bertanya lagi

"semua yang mati, akan kembali kepada-Nya." Beatrice kembali menjawab (Saraswati, 2017).

Kutipan tersebut merupakan percakapan antara Peter dan Beatrice. Peter yang masih ketakutan karena mendengar cerita dari Corrie bertanya pada ibunya tentang orang mati yang tidak kembali ke pangkuan Tuhan. Pada kutipan tersebut, Beatrice menejelaskan bahwa orang yang sudah meninggal pasti kembali ke pangkuan Tuhan. Sehingga kutipan tersebut termasuk dalam moral kepada Tuhan. Kutipan tersebut juga mengajarkan bahwa manusia datang dari Tuhan, yang sewaktu-waktu akan diambil oleh tuhan.

\section{Menghargai Tamu}

Paul Greef dan istrinya, Lucy menyambut kedatangan Van Gils di halaman luas di depan rumah mereka (Saraswati, 2017).

Kutipan di atas menggambarkan bagaimana perilaku atau adab dalam menerima tamu. Dalam kutipan di atas menceritakan mengenai Paul Greef dan Lucy yang tengah menunggu kedatangan Van Gils di halaman rumah mereka. Paul Greef dan Lucy begitu ramah dalam menyambut kedatangan keluarga Van Gils.

Berdasarkan pembahasan di atas pesan moral yang terdapat dalam novel tersebut adalah kasih sayang orang tua, nasionalisme, percaya diri, bersahabat, menghargai orang lain, sopan santun, peduli lingkungan, peduli sesama, religius, dan menghargai tamu.

\section{Relevansi Dengan Pembelajaran Bahasa Indonesia}

Pembelajaran novel sebagai media pembelajaran bahasa Indonesia sudah banyak dijabarkan oleh peneliti-penliti lain. Beberapa novel tersebut seperti Sepatu Dahlan Karya Khrisna Pabichara (Dewi, Ida, \& I Gede, 2014), Ayat-Ayat Cinta Karya Habibburakhman El Shirazy (Sunardi, 2016), Syarifah Karya Dul Abdul Rahman (Kartolo, 2017), Ibuk Karya Iwan Setyawan (Irma, 2018). Beberapa novel tersebut dapat dijadikan guru sebagai bahan referensi dalam pembelajaran bahasa Indonesia. Penggunaan novelnovel tersebut sebagai bahan pembelajaran, sudah melalui beberapa pertimbangan. Salah satunya adalah bahwa novel-novel tersebut bermuatan nilai-nilai pendidikan seperti pendidikan karakter dan religius. Pada penelitian ini diharapkan juga dapat dijadikan referensi guru sebagai bahan ajar bahasa Indonesia, karena dalam novel Peter karya Risa Saraswati ini mengandung nilai-nilai moral yang dapat diimplementasikan dalam pembelajaran. 
Penggunaan novel sebagai bahan Pembelajaran tidak luput dari kegiatan apresiasi. Kegiatan apresiasi merupakan suatu kegiatan menggauli serta memberikan penilaian terhadap suatu isi karya sastra. Kegiatan apresiasi bertujuan agar terbentuknya sikap mengahayati suatu karya sastra, sehingga timbullah suatu keinginan untuk merepresentasikan nilai-nilai yang terkandung dalam suatu karya sastra dalam kehidupan sehari-hari. Kegiatan apresiasi karya sastra merupakan suatu kegiatan yang dapat dilakukan oleh guru bahasa Indonesia dalam mengintegrasikan pendidikan moral kepada peserta didik atau siswa. Melalui kegiatan apresiasi ini diharapkan dapat merubah perilaku siswa menjadi lebih bermoral.

Keterampilan berbahasa dalam materi pembelajaran apresiasi sastra dapat dilakukan dengan: keterampilan membaca, siswa dapat diminta untuk membaca sebuah karya sastra. Setelah keterampilan membaca selesai dilakukan kemudian masuk ke dalam keterampilan menyimak, dan berbicara, siswa dapat mengungkapkan atau menceritakan kembali sebuah karya sastra yang sudah dibaca dalam bentuk lisan di depan kelas, kemudian siswa yang lain diminta untuk memberikan tanggapan. Pada keterampilan menulis siswa dapat diminta untuk menguraikan nilainilai dalam sebuah karya sastra, kemudian siswa dapat menuliskan sebuah cerita dengan memerhatikan nilai-nilai yang sudah didapat dari sebuah karya sastra yang lain.

Pemanfaatan novel Peter karya Risa Saraswati sebagai bahan ajar apresiasi karya sastra di madrasah kelas XI sangat dianjurkan. Hal ini berdasarkan uraian yang telah diajabarkan di atas, bahwa novel karya Risa Saraswati ini mengandung pesan moral yang patut dan layak untuk diteladani bagi pembaca, sehingga dapat digunakan sebagai bahan apresiasi karya sastra di madrasah. Hal tersebut sesuai dengan pendapat Waluyo (2011) yang menyatakan bahwa salah satu kriteria karya sastra sebagai bahan ajar adalah bahwa karya sastra harus bermuatan moral dan nilai-nilai edukatif. Pesan-pesan moral dan edukatif yang terkandung dalam novel yang sangat jarang dijumpai di novel-novel lain ini diharapkan dapat di contoh dan diteladani oleh peserta didik dalam kehidupan seharihari. Sehingga dengan mengimplementasikan apa yang sudah dibaca dalam novel, usaha pendidikan untuk membentuk peserta didik yang bermoral dapat terealisasikan dengan baik.

\section{SIMPULAN}

Novel sebagai salah satu dari berbagai jenis karya sastra, isinya tidak hanya cerita khalayan yang bersifat menghibur, mengkiritik. Akan tetapi juga memberikan pesan atau nilai-nilai kehidupan yang dapat diteladani oleh pembaca. Hal itu sesuai dengan fungsi karya sastra, bahwa karya sastra berfungsi sebagai media pendidikan bagi pembaca. Salah satunya yaitu nilai moral. Novel Peter karya Risa Saraswati ini menceritakan kehidupan teman hantu Risa bernama Peter semasa ia masih hidup. Kisah dalam balutan keluarga ini menyimpan banyak pesan moral yang dapat dijadikan bahan pembelajaran bagi pembaca, terutama bagi peserta didik. Adapun pesan moral yang terdapat dalam novel tersebut seperti: kasih 
sayang orang tua, nasionalisme, percaya diri, bersahabat, menghargai orang lain, sopan santun, peduli lingkungan, peduli sesama, religius, menghargai tamu. Melalui pesan moral tersebut, menjadikan novel ini relevan sebagai bahan pembelajaran bahasa Indonesia. Hal ini dikarenakan bahwa pendidikan tidak hanya sebagai transfer ilmu pengetahun namun juga pembentukan moral spiritual, sehingga melalui beberapa pesan moral yang terdapat dalam nvoel tersebut diharapkan dapat diteladani oleh pembaca terutama peserta didik.

\section{DAFTAR PUSTAKA}

Budiningsih, A. 2008. Pembelajaran Moral. Jakarta: PT Rineka Cipta.

Dewi, N. L. L. A., Ida, B. P., \& I Gede, N. 2014. Analisis Nilai-Nilai Pendidikan Karakter Novel Sepatu Dahlan Karya Khrisna Pabichara Dan Karakter Sekolah Di Indonesia. E-Jurnal Pendidikan Bahasa Dan Sasstra Indonesia, Undiksha, 2(1), 1-10.

Endawarsana, S. 2013. Sosiologi Sastra: Studi, Teori, dan Interpretasi. Yogyakarta: Penerbit Ombak.

Hidayat, A. 2014. Pembelajaran Moral Islami. Tadris, 9(1).

Irma, C. N. 2018. Nilai-Nilai Pendidikan Karakter Dalam Novel Ibuk Karya Iwan Setyawan. RETORIKA, 11(1), 14-22. https://doi.org/10.26858/retorika. v11i1.4888

Kartolo, R. 2017. Analisis Karakter Tokoh Protagonis Dan Antagonis Novel " Syarifah " Karya Dul Abdul Rahman Dengan Model Pembelajaran Kooperatif Siswa Kelas Vii Smp Muhammadiyah 04. Jurnal Penelitian Pendidikan Bahasa Dan Sast Ra, 2(1), 2-9.

Muhtadi, A. S. 2016. Pengantar Ilmu Jurnalistik. Bandung: Simbiosa Rekatama Media.
Mujiyanto, Y., \& Fuady, A. 2014. Kitab Sejarah Sastra Indonesia. Yogyakarta: Penerbit Ombak.

Muplihun, E. 2016. Nilai Moral dalam Dwilogi Novel Saman dan Larung Karya Ayu Utami. Jurnal Pendidikan Bahasa Dan Sastra Indonesia, 1(September), 58-64.

Ningrum, D. 2015. Kemerosotan Moral Di Kalangan Remaja: Sebuah penelitian Mengenai Parenting Styles dan Pengajaran Adab. UNISIA, XXXVII(82), 18-80.

Riyanti, A., \& Inung, S. 2017. Penggunaan Media Pembelajaran Sastra Bagi Guru Bahasa Indonesia. RETORIKA, 10(2), 106-111. https://doi.org/10.26858/retorika. $\mathrm{v}$

Rokhmansyah, A. 2014. Studi dan Pengkajian Sastra; Perkenalan Awal Terhadap Ilmu Sastra. Yogyakarta: Graha Ilmu.

Saraswati, R. 2017. Peter. Jakarta Selatan: Bukune.

Suhardi. 2018. Nilai Budaya Minangkabau Dalam Cerpen “ Cimuntu Lansie " Karya Wisran. Lingua Scientia, 10(1), 17-34.

Sunardi, A. 2016. Nila-Nilai Islami Dalam Novel Ayat-Ayat Cinta Karya Habibburakhman El Shirazy. Lingua, 12(1), 44-52. 
Nilai-Nilai Moral Novel Peter Karya Risa Saraswati Dan Relevansinya Dengan Pembelajaran Bahasa Indonesia

Trisnawati. 2018. Analisis Nilai Moral dan Nilai Sosial pada Kumpulan Cerpen Karya Ahmad Tohari sebagai Upaya Pemilihan Bahan Pembelajaran pada Siswa Kelas X SMAN 5. Artikula, 1(1), 1728.

https://doi.org/10.30653/006.201 811.9
Waluyo, H. J. 2011. Pengkajian dan Apresiasi Prosa Fiksi. Surakarta: UNS press.

Yusuf, S. 2004. Psikologi Perkembangan Anak dan Remaja. Bandung: PT Remaja Rosdakarya. 